\title{
Editorial
}

\section{Gonorrhoea: a continuing problem in the 1980s}

Recently, attention was drawn to the problem of $\beta$-lactamase-producing gonococci in the United Kingdom. ${ }^{1}$ These organisms were first reported in the UK in $1976,{ }^{23}$ and most reports have been of single sporadic cases. However, there was an outbreak in Liverpool in 1976 in which $\beta$-lactamase gonococci were isolated from 76 patients during the period from February to November of that year. ${ }^{4}$ These organisms had plasmids with a molecular weight similar to that found in isolates originating in Ghana and this may have been the origin of the outbreak in Liverpool, although epidemiological studies suggested that the outbreak may have originated in the city itself. ${ }^{4}$ Apart from this outbreak, most of the isolates found in the United Kingdom have been imported from West Africa or the Far East.' Laboratories have been requested to report such isolates, but only nine were reported in 1977 and 29 in 1978 whereas 25 were reported in the first six months of 1979.1

So far, reports from other countries have concerned sporadic cases. However, reports in this issue $^{5-7}$ show that these strains are becoming an increasing problem numerically in the Netherlands, accounting for $2-3 \%$ of all circulating gonococcal strains. $^{5}$ Furthermore, these $\beta$-lactamase strains appear to have established themselves in the local population-mainly in prostitutes-and imported strains accounted for only $14 \%$ of those identified in the first half of 1979.

In addition, $\beta$-lactamase-producing strains comprise $40 \%$ of isolates in some parts of the USA ${ }^{8}$ and Singapore. ${ }^{9}$ They are present in prostitutes in Hong Kong ${ }^{10}$ but appear to be less common in Lübeck, West Germany. ${ }^{11}$

The management of gonorrhoea continues to present a challenge. Initial antimicrobial treatment must be based on what is known of the probable sensitivity of the infecting strain of gonococcus. Careful follow up and rapid and vigorous contact tracing, especially where antimicrobial resistance is suspected, remain essential. It is vital to monitor antimicrobial sensitivity, to send all isolates with suspected $\beta$-lactamase production to a reference laboratory, and to disseminate information concerning resistance.

In the 1970s, there was a marked increase in the prevalence of gonorrhoea in most parts of the world, although there has been some levelling off in the UK during the second half of the decade.' During the 1970 s $\beta$-lactamase-producing strains were isolated and in 1979 they appear to have increased in number. What will the 1980s bring?

R N THIN

\section{References}

1. Sexually transmitted disease surveillance 1978. $\mathrm{Br}$ Med J 1979;ii: 1375-6.

2. Phillips I. $\beta$-lactamase-producing, penicillin-resistant gonococcus. Lancet 1976; ii:656-7.

3. Percival A, Rowlands J, Corkill JE, et al. Penicillinaseproducing gonococci in Liverpool. Lancet 1976; ii: 1379-82.

4. Arya OP, Rees E, Percival A, Alergant CD, Annels EH, Turner GC. Epidemiology and treatment of gonorrhoea caused by penicillinase-producing strains in Liverpool. Br J Vener Dis 1978;54:28-35.

5. Bijkerk H. Penicillinase-producing gonococci in the Netherlands. Br J Vener Dis 1980;56:243.

6. Nayyar KC, Noble RC, Michel MF, Stolz E. Gonorrhoea in Rotterdam caused by penicillinase-producing gonococci. $\mathrm{Br} \mathrm{J}$ Vener Dis 1980;56:244-8.

7. Nayyar KC, Michel MF, Stolz E. Antibiotic sensitivities of gonococci isolated in Rotterdam and results of treatment with cefuroxime. $\mathrm{Br} J$ Vener Dis 1980;56:249-51.

8. Berg SW, Kilpatrick ME, Harrison WO, McCutchan JA. Cefoxitin as a single-dose treatment for urethritis caused by penicillinase-producing Neisseria gonorrhoeae. N Engl J Med 1979; 301: 509-11.

9. Rajan VS, Sng EH, Pang R, Tan NJ, Thirumoorthy T, Yeo KL. HR 756: A new cephalosporin, in the treatment of gonorrhoea caused by ordinary and penicillinase-producing strains of Neisseria gonorrhoeae. Br J Vener Dis 1980; 56:255-8.

10. Wang FH. $\beta$-lactamase-producing gonococci in Hong Kong. $\mathrm{Br}$ $J$ Vener Dis 1980;56:270.

11. Grunder K, Petzoldt D. Sensitivity of Neisseria gonorrhoeae to spectinomycin and thiamphenicol. $B r J$ Vener Dis 1980;56:252-4. 